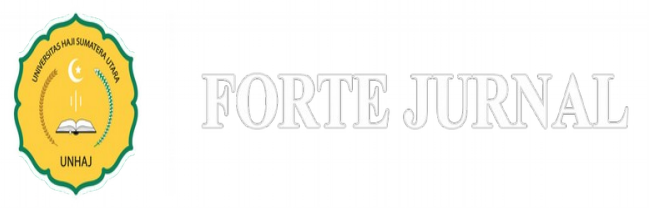

FORTE JOURNAL

e-ISSN 2774-4655

Vol 1, No 1, Januari 2021

Hal 01-11

\title{
UJI EFEKTIVITAS ANTIDIARE EKSTRAK ETANOL DAUN MENGKUDU (Morinda citrifolia L.) TERHADAP MENCIT JANTAN DENGAN METODE TRANSIT INTESTINAL
}

\author{
Robiatun Rambe ${ }^{1}$, Evi Depiana Gultom ${ }^{2 *}$, Ovalina Sylvia Br. Ginting ${ }^{3}$, Shela Diana ${ }^{4}$ \\ ${ }^{1,3,4}$ Universitas Haji Sumatea Utara, Medan, Indonesia \\ ${ }^{2}$ Institusi Deli Tua Deli Husada, Deli Serdang, Indonesia \\ *Email: evidepiana1@gmail.com
}

\begin{abstract}
Abstrak
Mengkudu (Morinda citrifolia L.) merupakan tumbuhan dari famili Rubiceae, yang secara tradisional digunakan sebagai meningkatkan daya tahan tubuh, antiinflamasi, analgesik, antibakteri, antidiare, mencegah hipertensi, mengobati perut mual dan kembung, mengobati peradangan lambung dan usus. Kandungan metabolit sekunder triterpenoida/steroida, tanin, saponin, dan flavonoida yang dapat digunakan untuk mengobati diare. Tujuan penelitian ini untuk mengetahui karakterisasi, skrining fitokimia dan uji aktivitas antidiare ekstrak etanol daun situduh langit terhadap mencit jantan yang diinduksi dengan oleum ricini. Serbuk simplisia daun mengkudu dikarakterisasi dan diskrining fitokimia, kemudian diekstraksi dengan pelarut etanol $70 \%$ secara maserasi. Ekstrak yang diperoleh diuji efek antidiare terhadap mencit jantan yang diinduksi oleum ricini menggunakan metode transit intestinal yaitu dengan cara menghitung persen lintas yang dilewati tinta cina sebagai marker dan loperamid HCL dosis $0,52 \mathrm{mg} / \mathrm{kg}$ bb sebagai pembanding. Dosis ekstrak yang digunakan adalah 50, 100, dan $150 \mathrm{mg} / \mathrm{kg} \mathrm{bb}$. Hasil karakteristik serbuk simplisia diperoleh kadar air 10\%, kadar sari larut air 6\%, kadar sari larut etanol 16\%, kadar abu total 9,5\% dan kadar abu tidak larut asam 0,5\%. Hasil skrining fitokimia diperoleh senyawa triterpenoida/steroida, tanin, saponin, flavonoida dan glikosida. Ekstrak etanol daun mengkudu dosis 50 dan $100 \mathrm{mg} / \mathrm{kg}$ bb memiliki efek antidiare sebanding dengan loperamid $\mathrm{HCl}$ dosis $0,52 \mathrm{mg} / \mathrm{kg} \mathrm{bb}$, sedangkan dosis $40 \mathrm{mg} / \mathrm{kg}$ bb memiliki efek antidiare yang lemah $(\mathrm{P}<0,05)$.
\end{abstract}

Kata kunci: antidiare, ekstrak etanol daun mengkudu, karakterisasi, skrining fitokimia

\begin{abstract}
Mengkudu (Morinda citrifolia L.) is a plant from the Rubiceae family, which is traditionally used as an immune booster, anti-inflammatory, analgesic, antibacterial, anti-diarrheal, prevents hypertension, treats stomach nausea and bloating, treats inflammation of the stomach and intestines. The content of secondary metabolites triterpenoids / steroids, tannins, saponins, and flavonoids which can be used to treat diarrhea. The purpose of this study was to determine the characterization, phytochemical screening and antidiarrheal activity test of the ethanol extract of the celestial leaves against male mice induced by oleum ricini. Mengkudu leaf simplicia powder was characterized and screened for phytochemistry, then extracted with ethanol $70 \%$ by maceration as a solvent. The extract obtained was tested for the anti-diarrheal effect of male mice induced by oleum ricini using the intestinal transit method, namely by calculating the percent of
\end{abstract}


passage passed by Chinese ink as a marker and HCL loperamid dose of $0.52 \mathrm{mg} / \mathrm{kg} \mathrm{bw}$ as a comparison. The extract doses used were 50, 100, and $150 \mathrm{mg} / \mathrm{kg} \mathrm{BW}$. The results of the characteristics of the simplicia pollen obtained water content of $10 \%$, water soluble extract content of $6 . \%$, ethanol soluble extract content of $16 . \%$, total ash content of $9.5 \%$ and acid insoluble ash content of $0.5 \%$. The results of phytochemical screening obtained compounds of triterpenoids / steroids, tannins, saponins, flavonoids and glycosides. The ethanol extract of noni leaves at a dose of 50 and $100 \mathrm{mg} / \mathrm{kg} \mathrm{BW}$ has an anti-diarrheal effect comparable to that of loperamid $\mathrm{HCl}$ at a dose of $0.52 \mathrm{mg} / \mathrm{kg}$, while a dose of $40 \mathrm{mg} / \mathrm{kg} \mathrm{BW}$ has a weak antidiarrheal effect $(P<0.05)$.

Keywords: antidiarrheal, ethanol extract of noni leaves, characterization, phytochemical screen

\title{
Pendahuluan
}

Indonesia merupakan salah satu negara dengan kekayaan hayati terbesar di dunia yang memiliki lebih dari 30.000 spesies tanaman tingkat tinggi. Salah satu tumbuhan yang sering digunakan oleh masyarakat sebagai obat tradisional antidiare adalah daun mengkudu (Widiana et.al., 2011). Tumbuhan mengkudu memiliki berbagai kandungan senyawa metabolit, yang sudah diketahui, antara lain golongan alkaloid,flavonoid, triterpenoid, tanin, saponin dan antrakuinon (Musfirah et.al., 2019) Senyawa tannin yang bersifat adstringen inilah yang mengakibatkan daun mengkudu dapat digunakan sebagai obat antidiare, karena dapat menciutkan selaput lendir sehingga penyerapan air akan lebih banyak di absorbsi dan juga memperlambat proses defekasi (Ganiswarna, 2005). Sedangkan senyawa flavonoid yang terkandung dalam daun mengkudu dapat menghambat motilitas usus sehingga mengurangi sekresi cairan dan elektrolit (Thahir, 2019). Penyakit diare atau juga sering disebut gastroenteritis adalah defekasi yang sering dalam sehari dengan feses yang lembek atau cair, terjadi karena chymus yang melewati usus kecil dengan cepat, kemudian feses melewati usus besar dengan cepat pula sehingga tidak cukup waktu untuk absorpsi.

Daya Hambat Ekstrak Daun Mengkudu (Morinda citrifolia L.) Terhadap Pertumbuhan Bakteri Penyebab Diare. Menunjukkan Daun mengkudu dapat menghambat pertumbuhan bakteri Escherichia coli dan bakteri Salmonella sp. Dimana bakteri ini dapat menyebabkan diare (Rina et.al., 2019).

\section{Metode Penelitian}

Penelitian ini dilakukan secara eksperimental dengan tahapan penelitian yaitu penyiapan sampel, pembuatan ekstrak, penyiapan hewan dan pengujian efek antidiare pada hewan percobaan. Data hasil penelitian dianalisis secara ANOVA (analisis of variasi) dan dilanjutkan dengan uji beda Tukey menggunakan program SPSS (Statisyikal Prosuct and Service Solution) versi 18.0.

\section{Lokasi Penelitian}

Penelitian dilakukan di Laboratorium Farmakologi Universitas Haji Sumatra Utara.

\begin{abstract}
Alat dan Bahan
Alat-alat

Alat-alat yang digunakan dalam penelitian ini adalah alat-alat gelas laboratorium, alumunium foil, belender (Panasonic) cawan porselen (haldenwanger), kaca object (slides), kaca penutup (iso lab), kandang hewan, kain flanel, meja bedah hewan, neraca hewan (Presica Geniweigher GW-1500), neraca Analitik (ohous), mikroskop (olimpus)
\end{abstract}


oral sonde, lumpang, stamfer, kertas saring, seperangkat alat bedah hewan, spuit $1 \mathrm{ml}$ (Terumo), pipet tetes, rotary evaporator.

Bahan

Bahan tumbuhan yang digunakan pada penelitian ini adalah daun mengkudu, Bahan yang digunakan adalah minyak jarak, tinta cina, Na-CMC, tablet lodia (sanbe), dan semua bahan kimia yang digunakan berkualitas pro analisis kecuali dinyatakan lain adalah kloralhidrat, etanol teknis $(70 \%)$, pereaksi Bouchardat, pereaksi Dragendroff, pereaksi Meyer, besi (III) klorida, timbal (II) asetat, amil alkohol, asam klorida, serbuk Magnesium, akuades.

\section{Hewan uji}

Hewan yang digunakan adalah Mencit jantan (Mus muculus) diperoleh dari Kampus Universitas Islam Negeri Sumatera Utara.

\section{Skrining fitokimia simplisia dan EEDM}

Skrinning fitokimia simplisia daun mengkudu meliputi pemeriksaan senyawa alkaloid, saponin, flavonoid, tanin, glikosida.

\section{Pembuatan ekstrak etanol daun mengkudu}

Daun mengkudu dicuci dan dibersihkan dari partikel asing dan ditiriskan, lalu dipotong kecil dan dikeringkan menggunakan lemari pengering, setelah kering sampel dihaluskan menggunakan blender. Ekstraksi dilakukan secara maserasi menggunakan pelarut etanol $70 \%$ dengan mengambil sejumlah 500 gram serbuk kering simplisia (satu bagian) dimasukkan kedalam maserator, ditambahkan 10 bagian etanol $70 \%$ (5 liter). Direndam selama 6 jam pertama sambil diaduk sekali-sekali, kemudian didiamkan selama $18 \mathrm{jam}$. Dipisahkan maserat dengan cara filtrasi. Diulangi proses penyarian sebanyak tiga kali menggunakan jenis pelarut yang sama dan jumlah volume pelarut setengah kali jumlah volume pelarut pada penyarian pertama. Dikumpulkan semua maserat, kemudian dipekatkan dengan rotary evaporator pada suhu $50^{\circ} \mathrm{C}$, kemudian diuapkan di atas penangas air hingga diperoleh ekstrak kental (Depkes RI, 2013).

\section{Persiapan pengujian efek antidiare EEDM}

Persiapan pengujian efek antidiare meliputi penyiapan hewan percobaan, penyiapan bahan uji, bahan kontrol positif, suspensi EEDM sebagai bahan uji, minyak jarak sebagai penginduksi diare, marker dan pengujian efek antidiare.

\section{Penyiapan hewan percobaan}

Hewan yang digunakan adalah mencit jantan dengan berat 20 - 30 g sebanyak 24 ekor, dibagi dalam 6 kelompok, setiap kelompok terdiri dari 4 ekor mencit. Sebelum digunakan mencit di aklimitasi selama 2 minggu dengan tujuan untuk menyeragamkan makanan dan hidupnya dengan kondisi yang serba sama sehingga dianggap memenuhi syarat untuk penelitian.

\section{Penyiapan bahan}

Bahan yang digunakan meliputi suspensi Na-CMC sebagai kontrol negatif, suspensi Lodia sebagai kontrol positif, suspensi EEDM sebagai bahan uji, minyak jarak sebagai penginduksi diare dan dan tinta cina sebagai marker.

\section{Pembuatan suspensi Na-CMC 0,5\% (b/v)}


Sebanyak $500 \mathrm{mg}$ Na-CMC ditaburkan kedalam lumpang yang berisi air suling panas. Didiamkan selama 15 menit lalu digerus hingga diperoleh massa yang transparan, digerus sampai homogen. Diencerkan dengan air suling, dihomogenkan dan dimasukkan ke labu tentukur, dicukupkan volumenya dengan air suling hingga $100 \mathrm{ml}$ (Anief M, 1995).

\section{Pembuatan suspensi Loperamid $0,052 \%$}

Satu tablet Lodia mengandung $2 \mathrm{mg}$ loperamid HCL. Sebanyak 20 tablet ditimbang, digerus halus dalam lumpang, kemudian timbang serbuk setara 0,52 $\mathrm{mg}$ loperamid HCL. Serbuk yang ditimbang dimasukkan kedalam lumpang kemudian ditambah suspensi $\mathrm{Na}-\mathrm{CMC}$ 0,5\% sedikit demi sedikit sambil digerus homogen, kemudian diencerkan hingga $10 \mathrm{ml}$ (Anief M, 1995).

\section{Pembuatan suspensi EEDM konsentrasi 0,5\%, 1\%, 2\%, dan 4\%.}

Suspensi EEDM dibuat dalam 3 variasi konsentrasi yaitu $1 \%, 2 \%$ dan $4 \%$. Sebanyak 100, 200, $400 \mathrm{mg}$ ekstrak etanol daun mengkudu ditimbang, kemudian dimasukkan kedalam lumpang dan ditambahkan suspensi Na-CMC 0,5\% sedikit demi sedikit sambil digerus hingga homogen. Suspensi kemudian dimasukkan ke dalam labu tentukur dan dicukupkan volumenya sampai $10 \mathrm{ml}$ (Anief M, 1995).

\section{Pengujian aktivitas antidiare EEDM}

Dosis EEDM yang digunakan dalam pengujian ini adalah 50, 100, dan $150 \mathrm{mg} / \mathrm{kg}$ bb. Pengujian yang dilakukan meliputi uji aktivitas antidiare EEDM pada mencit jantan yang diinduksi oleh minyak jarak dan uji aktivitas antimotilitas dengan metode transit intestinal.

Pelaksanaan percobaan ini menggunakan 24 ekor mencit yang dibagi secara acak kedalam 6 kelompok perlakuan, Sebelum percobaan dimulai, mencit dipuasakan selama 18 jam tetapi tetap diberi minum. Kelompok I yaitu kelompok kontrol negatif diberi suspensi $\mathrm{Na}-\mathrm{CMC} 0,5 \%$ dosis $50 \mathrm{mg} / \mathrm{kg}$ bb secara oral, kelompok II-V diberi EEDM dengan dosis 50,100 dan $150 \mathrm{mg} / \mathrm{kg}$ bb secara oral sedangkan kelompok VI yaitu kelompok pembanding diberi loperamid dosis $0,52 \mathrm{mg} / \mathrm{kg}$ bb secara oral (Chitme, et al., 2004).

Satu jam setelah perlakuan, semua mencit diberikan minyak jarak sebanyak 0,5 $\mathrm{ml}$ minyak jarak. Setelah 1 jam pemberian minyak jarak, diberikan tinta cina sebanyak $0,1 \mathrm{ml} / 10$ gram mencit secara oral sesuai dengan penelitian yang dilakukan Khori Yusnita 2018. Setelah 1 jam pemberian tinta cina semua hewan dikorbankan dengan cara dislokasi tukang leher. Hewan dibedah dan usunya dikeluarkan secara hati-hati (Chitme, 2004).

Diukur panjang usus yang dilalui marker tinta cina mulai dari pylorus dan katup ileosekal setiap hewan. Kemudian dari masing-masing hewan dihitung persen lintasan yang dilalui oleh marker tinta cina terhadap panjang usus seluruhnya (Chitme, 2004).

\section{Analisis Data}

Nilai rasio kemudian dirata-ratakan masing-masing kelompok dan nilai dari masing-masing kelompok tersebut dibandingkan dengan kelompok lainnya. Data hasil pengamatan dianalisis secara statistik dengan metode ANOVA (analisis of variasi). Analisis statistik ini menggunakan program SPSS (Statistikal Product and Service Solution) versi 18.0.

\section{Hasil dan Pembahasan}




\section{Hasil Karaktrisasi}

\section{Pemeriksaan makrospik}

Helaian daun umumnya utuh, berwarna hijau sampai hijau tua kekuningan, bentuk bundar telur, lebar hingga berbentuk elip, panjang 4,5 cm sampai $21 \mathrm{~cm}$, lebar 4,5 $\mathrm{cm}$ sampai $8 \mathrm{~cm}$, ujung daun runcing, pangkal daun meruncing, pinggir daun rata. Daun penumpu berbentuk bundar telur, pinggir rata warna hijau kekuningan, panjang $0,5 \mathrm{~cm}$ sampai $1,5 \mathrm{~cm}$. Tulang daun menyirip jelas.

\section{Pemeriksaan karakterisasi serbuk simplisia daun mengkudu} pada tabel 1 .

Penetapan hasil karakteristik dari serbuk simplisia daun mengkudu dapat dilihat

Tabel 1. Hasil karakteristik dari serbuk simplisia daun mengkudu

\begin{tabular}{llcl}
\hline No & Karakteristik Serbuk Simplisia & Kadar & $\begin{array}{c}\text { Persyaratan MMI } \\
\text { (Physallis minima } \mathbf{L})\end{array}$ \\
\hline 1 & Kadar air & $10 \%$ & Tidak lebih dari $10 \%$ \\
2 & Kadar sari larut dalam air & $6 \%$ & Tidak kurang dari $3,5 \%$ \\
3 & Kadar sari larut dalam etanol & $16 \%$ & Tidak kurang dari $9,5 \%$ \\
4 & Kadar abu total & $9,5 \%$ & Tidak lebih dari $12 \%$ \\
5 & Kadar abu tidak larut asam & $0,5 \%$ & Tidak lebih dari $0,5 \%$ \\
\hline
\end{tabular}

Penetapan kadar air dilakukan untuk mengetahui besarnya kandungan air yang terdapat dalam serbuk simplisia. Menurut Materia Medika Indonesia (1995), syarat kadar air yang baik tidak lebih dari $10 \%$. Kadar air yang diperoleh adalah $10 \%$ dimana hasil ini memenuhi persyaratan.

Metode penentuan kadar sari larut air maupun larut etanol bertujuan untuk menentukan jumlah senyawa aktif yang terekstraksi dalam pelarut dari sejumlah serbuk simplisia. Hasil pengujian menunjukkan kadar sari larut air dari serbuk simplisia daun mengkudu memiliki nilai $6 \%$, sedangkan kadar sari larut etanol sebesar $16 \%$. Hal ini menunjukkan bahwa jumlah senyawa polar yang terlarut dalam air lebih kecil daripada jumlah senyawa kurang polar (semi polar maupun non polar) yang terlarut dalam etanol, selain itu dapat merupakan indikator banyaknya zat berkhasiat yang dapat tersari oleh pelarut air dan etanol (Isnawati et.al., 2006).

Penetapan kadar abu total bertujuan untuk mengetahui kadar senyawa-senyawa anorganik seperti oksida logam $\mathrm{Mg}, \mathrm{Ca}, \mathrm{Pb}$, dan $\mathrm{Zn}$. Penetapan kadar abu tidak larut dalam asam dilakukan untuk mengetahui kadar senyawa yang tidak larut dalam asam . Hasil yang didapat untuk kadar abu total adalah kadar abu tidak larut dalama asam adalah sebesar $9,5 \%$ dan $0,5 \%$. Hasil perhitungan dari pemeriksaan karakterisasi simplisia daun mengkudu dapat dilihat pada lampiran 6 halaman 60

\section{Hasil Skrining Fitokimia}

Hasil skrining fitokimia terhadap serbuk simplisia daun situduh langit dilakukan terhadap golongan senyawa triterpenoida/steroida, alkaloida, tanin, saponin, flavonoida, dan glikosida. Pemeriksaan golongan senyawa triterpenoida/steroida dengan penambahan beberapa tetes pereaksi Liebermann- Burchard menghasilkan warna merah muda atau ungu. Pemeriksaan golongan senyawa alkaloida dengan penambahan pereaksi Mayer, 
Bouchardat, dan Dragendorff, dimana tidak terdapat endapan yang menunjukkan tidak adanya golongan senyawa alkaloida. Penambahan $\mathrm{FeCl}_{3}$ memberikan warna hijau kecoklatan yang menunjukkan adanya golongan senyawa tanin.. Serbuk simplisia dengan penambahan akuades panas dan dikocok kuat menghasilkan busa yang stabil kemudian ditambah $\mathrm{HCl} 2 \mathrm{~N}$, menunjukkan adanya golongan senyawa saponin. Pemeriksaan golongan senyawa flavonoida dengan penambahan serbuk magnesium dan asam klorida pekat menghasilkan larutan yang berwarna merah. Pemeriksaan golongan senyawa glikosida dengan penambahan pereaksi Molisch dan asam sulfat pekat membentuk cincin ungu. Hasil skrining fitokimia terhadap serbuk simplisia daun situduh langit selanjutnya dapat dilihat pada tabel 2.

Tabel 2. Hasil skrining fitokimia serbuk simplisia daun mengkudu

\begin{tabular}{|c|c|c|}
\hline No & Golongan senyawa & $\begin{array}{c}\text { Hasil } \\
\text { Serbuk simplisia }\end{array}$ \\
\hline 1 & Triterpenoida/steroida & + \\
\hline 2 & Alkaloida & + \\
\hline 3 & Tanin & + \\
\hline 4 & Saponin & + \\
\hline 5 & Flavonoida & + \\
\hline 6 & Glikosida & + \\
\hline
\end{tabular}

Keterangan: $\quad(+)$ Positif : mengandung golongan senyawa

(-) Negatif : : tidak mengandung golongan senyawa

Hasil Skrining Fitokimia serbuk simplisia daun mengkudu ini sudah sesuai dengan Peneliti sebelum nya "Analisis Kualitatif Dan Analisis Kuantitatif Dari Ekstrak Heksan, Aseton, Etanol, Dan Air Dari Daun Mengkudu (Morinda Citrifolia L.)" Oleh saudara Rusdi dkk. 2015.

\section{Hasil Ekstraksi}

Ekstraksi dilakukan dengan metode maserasi, hasilnya dari $500 \mathrm{~g}$ serbuk simplisia daun situduh langit diperoleh ekstrak kental sebanyak 52 g. Hasil rendemen yang diperoleh adalah 10,4\%. Perhitungan rendemen dapat dilihat pada Lampiran 13 halaman 70 .

\section{Pengujian Efek Antidiare}

Sebelum dilakukan pengujian efek antidiare, Mencit dipuasakan terlebih dahulu selama 18 jam dengan tetap diberi minum, untuk mengosongkan usus agar mempermudah proses absorpsi pada saluran cerna dan mempermudah dalam pengukuran lintasan marker tinta cina pada usus tikus. Tikus yang digunakan dalam pengujian memiliki berat badan 20-30 g. Dosis EEDM yang digunakan dalam pengujian ini adalah $50 \mathrm{mg} / \mathrm{kgBB}, 100 \mathrm{mg} / \mathrm{kgBB}, 150 \mathrm{mg} / \mathrm{kgBB}$. Semua perlakuan diberikan secara oral. Tikus dikelompokkan menjadi 6 kelompok dimana setiap kelompok terdiri dari 5 ekor. Kelompok I diberi tinta cina $1 \mathrm{ml}$, kelompok II diberi oleum ricini $2 \mathrm{ml}$ dan tinta cina 1 $\mathrm{ml}$, kelompok III, IV, V diberi EEDSL masing-masing dosis 50, 100, dan $150 \mathrm{mg} / \mathrm{kg}$ bb. Kelompok VI diberi loperamid $\mathrm{HCl}$ dosis $1 \mathrm{mg} / \mathrm{kg}$ bb. 
Penggunaan tinta cina adalah sebagai marker dalam pengukuran metode transit intestinal. Oleum ricini atau minyak jarak mengandung komponen aktif asam risinoleat yang dapat menginduksi perubahan permeabilitas pada cairan mukosa dan transport elektrolit yang menghasilkan respons hipersekretori dan diare. Asam risinoleat dapat meningkatkan sekresi air dan elektrolit ke dalam usus halus. Pembebasan asam risinoleat dari minyak jarak menyebabkan iritasi dan pembengkakan mukosa usus, yang menyebabkan pelepasan prostaglandin, sehingga dapat meningkatkan sekresi dan motilitas intestinal (Inayathulla, et al., 2010).

Loperamid digunakan sebagai pembanding karena dapat memulihkan sel yang berada dalam kondisi hipersekresi ke keadaan resorpsi normal, dan dapat meningkatkan waktu transit usus halus dan absorbsi air, natrium dan klorida dalam tubuh bila terjadi gangguan elektrolit. Loperamid memiliki efek konstipasi dengan memperlambat motilitas saluran cerna dan laju aliran pada usus hingga menuju kolon serta menormalkan keseimbangan absorbsi dan sekresi cairan pada membran mukosa usus, selain itu loperamid merupakan agen antidiare yang paling banyak digunakan dan efektif terhadap minyak jarak karena bersifat sebagai antimotilitas dan antisekretorik (Anas et.al., 2016).

Hasil uji efek antidiare dari EEDSL pada tikus putih jantan diperoleh persentase lintasan marker yang dapat dilihat pada Tabel 3 dan grafik persen lintasan marker pada Gambar 1.

Tabel 3. Persentase lintasan marker tinta cina pada usus tikus

\begin{tabular}{|c|c|c|c|c|c|}
\hline \multirow{2}{*}{$\begin{array}{c}\text { Hewan } \\
\text { uji }\end{array}$} & \multirow[b]{2}{*}{ CMC } & \multicolumn{3}{|c|}{ EEDSL (mg/kg bb) } & \multirow{2}{*}{$\begin{array}{c}\text { Loperamid } \\
\text { HCl }\end{array}$} \\
\hline & & 50 & 100 & 150 & \\
\hline 1 & $83,60 \%$ & $36,13 \%$ & $42,18 \%$ & $52,63 \%$ & $36,20 \%$ \\
\hline 2 & $88,50 \%$ & $38,70 \%$ & $41,58 \%$ & $51,16 \%$ & $39,68 \%$ \\
\hline 3 & $77,19 \%$ & $36,20 \%$ & $45,83 \%$ & $50,84 \%$ & $38,46 \%$ \\
\hline 4 & $91,66 \%$ & $48,19 \%$ & $50,84 \%$ & $56,67 \%$ & $34,48 \%$ \\
\hline $\begin{array}{c}\text { Rata-rata } \\
\quad \pm \mathrm{SE}\end{array}$ & $\begin{aligned} & 85,23 \% \\
\pm & 3,15\end{aligned}$ & $\begin{array}{c}39,80 \% \\
\pm 2,8\end{array}$ & $\begin{array}{c}45,10 \% \\
\pm 2,1\end{array}$ & $\begin{array}{c}52,82 \% \\
\quad \pm 1,0\end{array}$ & $\begin{array}{l}37,20 \% \\
\pm 1,2\end{array}$ \\
\hline
\end{tabular}


Keterangan: Tikus kondisi normal, tikus uji yang diberi EEDSL dosis $50 \mathrm{mg} / \mathrm{kg}$ $\mathrm{bb}, 100 \mathrm{mg} / \mathrm{kg} \mathrm{bb}, 150 \mathrm{mg} / \mathrm{kg}$ bb dan loperamid $\mathrm{HCl}$ dosis 0,52 $\mathrm{mg} / \mathrm{kg} \mathrm{bb}$.

Hasil pengujian aktivitas antidiare kemudian dianalisa dengan uji perbedaan ratarata antar kelompok (uji ANOVA) menunjukkan adanya hubungan bermakna $(\mathrm{P}<0,05)$ yang berarti terdapat perbedaan yang signifikan antar perlakuan. Pengujian dilanjutkan dengan uji Tukey yang menunjukkan bahwa dosis 50 dan $100 \mathrm{mg} / \mathrm{kg}$ bb tidak jauh berbeda dengan pemberian loperamid $\mathrm{HCl} 0,5 \mathrm{mg} / \mathrm{kg}$ bb, maka dapat dinyatakan bahwa dosis 50 dan $100 \mathrm{mg} / \mathrm{kg}$ bb dapat digunakan sebagai antidiare yang dilihat dari penurunan persen lintasan marker tinta cina,

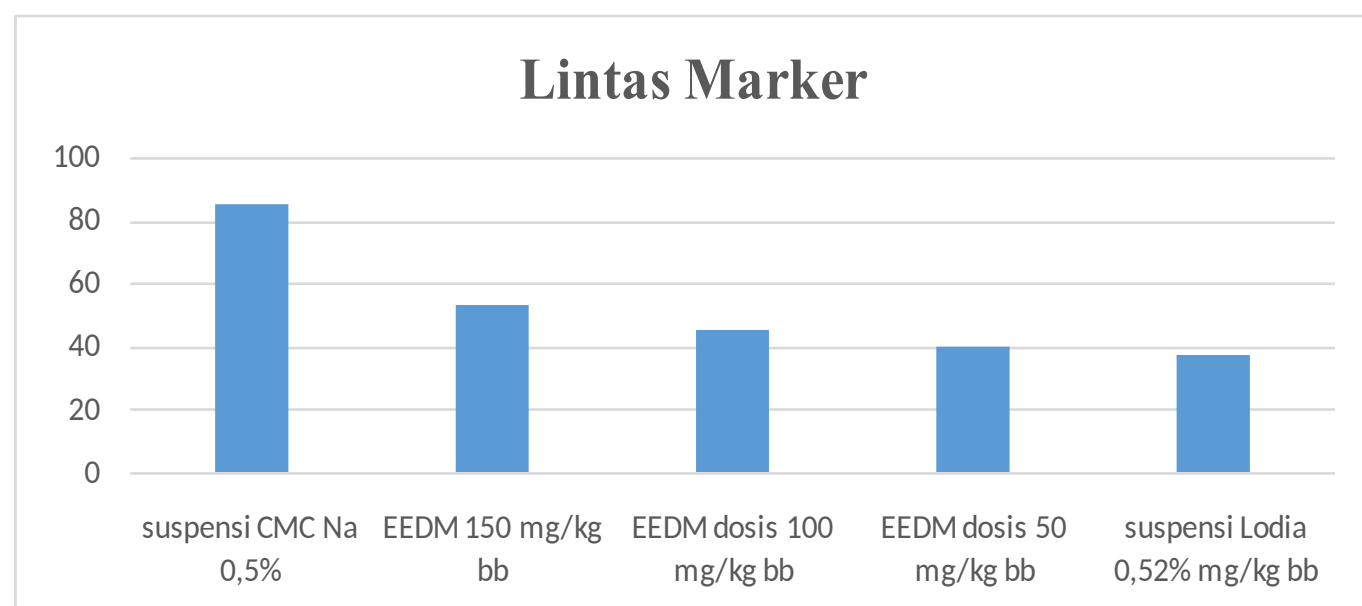

Gambar 1. Grafik persentase perubahan lintasan marker tinta cina pada usus tikus kondisi normal, tikus diare, tikus yang diberi EEDM dosis 50,100, dan $150 \mathrm{mg} / \mathrm{kg} \mathrm{bb}$, dan mencit yang diberi loperamid $\mathrm{HCl}$ dosis $0,52 \mathrm{mg} / \mathrm{kg}$ bb.

Daun Mengkudu dapat digunakan sebagai antidiare karena mengandung metabolit sekunder seperti: tanin ,saponin, dan flavonoida. Senyawa steroida sebagai antidiare dapat meningkatkan absorpsi air dan elektrolit dalam usus, sehingga mengakibatkan absorbsi air dan elektolit dalam usus normal kembali (Anas et.al., 2012). Tanin diketahui mempunyai aktivitas antiinflamasi, adstringen, antidiare, diuretik dan antiseptik, selain itu tanin berfungsi memperlancar sistem pencernaan, dan sirkulasi darah. Sifat pengelat tanin mempunyai efek spasmolitik, dimana dapat mengkerutkan usus sehingga gerak peristaltik usus berkurang, dan dapat mengendapkan protein pada permukaan usus. Sifat adstringen tanin akan membuat usus halus lebih tahan terhadap 
rangsangan senyawa kimia yang mengakibatkan diare. Tanin juga terbukti membantu melindungi usus dari iritasi yang diakibatkan oleh pemberian oleum ricini (Fajrin, 2012).

Mekanisme flavonoida sebagai antidiare dapat menghambat motilitas usus, mengurangi sekresi air dan elektrolit (Fajrin, 2012), serta memperlama waktu transit usus (Anas et.al., 2016). Flavonoida, terpen dan gula juga menunjukkan aktivitas sebagai antidiare. Kandungan senyawa aktif yang diduga berkontribusi besar terhadap efek antidiare adalah steroida, tanin, flavonoida, dan saponin, sifat antidiare tanaman obat disebabkan oleh tanin, saponin, flavonoida dan sterol. Senyawa aktif golongan saponin memiliki efek antidiare dengan menghambat pelepasan histamin secara in vitro (Anas et.al., 2016).

\section{Kesimpulan}

Berdasarkan hasil penelitian yang dilakukan dapat disimpulkan bahwa:

1. Karakteristik serbuk simplisia mengkudu kadar air 10\%, kadar sari larut dalam air $6,6 \%$, kadar sari larut dalam etanol 16\%, kadar abu total 9.5\% dan kadar abu yang tidak larut asam $0,5 \%$.

2. Skrining fitokimia serbuk simplisia daun mengkudu diperoleh adanya senyawa triterpenoida/steroida, tanin, saponin, flavonoida dan glikosida.

3. Pengujian efek antidiare ekstrak etanol daun mengkudu (EEDSM) diperoleh dosis 50,100 , dan $150 \mathrm{mg} / \mathrm{kg}$ bb memiliki efek antidiare, tetapi dosis 50 dan 100 $\mathrm{mg} / \mathrm{kg} \mathrm{bb}$ memiliki efek yang signifikan dengan loperamid $\mathrm{HCl}$ dosis 0,52 $\mathrm{mg} / \mathrm{kg}$ bb.

\section{Referensi}

Adyana, Ketut. 2004. "Efek Ekstrak Daun Jambu Biji Daging Buah Putih Dan Jambu Biji Daging Buah Merah Sebagai Antidiare”. Bandung: Departemen Farmasi Institut Teknologi Bandung.

Agoes, 2007. “Teknologi Sediaan Alam”. ITB Press Bandung.

Ambarwati, D. R. 2018. "Uji Aktivitas Infusa Daun Kersen Dan Serbuk Instan Perasan Daun Kersen (Muntingia calabura L.) Tterhadap Peningkatan Daya Ingat Mencit Putih (Mus musculus) Dengan Metode Morris Water Maze”. Surakarta: Universitas Setia Budi Surakarta.

Anwar, 2000 ; Anggun Purwaningsih Utami. 2019. "Uji Efektifitas Antidiare Ekstrak Etanol Daun Beluntas (Pluchea Indica L.) Terhadap Mencit Jantan (Mus musculus). Stikes Bhakti Husada Mulia Madiun.

Atikaningrum, D. J. 2011, Perbadingan Efektifitas Analgesik Ekstrak Daun Sirih Merah (Piper crocatum) Dengan Aspirin Dosis Terapi Pada Mencit, Fakultas Kedokteran, Universitas Sebelas Maret, Surakarta.

EM Sutrisna. 2016. "Herbal Medicine : Suatu Tinjauan Farmakologis". Surakarta : Muhammadyah Universitas Press. Hal 13.

Endang, Hanani. 2015. “ Analisis Fitokimia”. Jakarta : Penebar Swadaya Hal. 17-18.

Dalimarta, S. 2006. "Atlas Tumbuhan Obat Indonesia 2011”. Jakarta: Puspa Swara. Hal 57.

DepKes RI. 1995. Farmakope Indonesia. Edisi IV. Jakarta. Dapartemen Kesehatan RI. Hal 19. 
Dijten POM. 1979 ; Shaleh, Miftah Ulfah. 2016. “Uji Efek Antidiare Ekstrak Etanol Daun Kacang Gude (Cajanus Cajan (L.) Milla sp) Pada Mencit (Mus muculus). Makassar: Universitas Islam Negri Allaudin.

Fatmawati, Sri. 2019. "Bioaktivitas dan Konstituen Kimia Tanaman Obat Indonesi". Yogyakarta: DEEPUBLISH. Hal 86.

Ganiswarna, Sulistia. G. 2005. "Farmakologi Dan Terapi Edisi IV”. Jakarta: Bagian Farmakologi Fakultas Kedokteran Universitas Indonesia.

Hadi. 2002 ; Shaleh, Miftah Ulfah. 2016. "Uji Efek Antidiare Ekstrak Etanol Daun Kacang Gude (Cajanus Cajan (L.) Milla sp) Pada Mencit (Mus muculus). Makassar: Universitas Islam Negri Allaudin.

Hanani, Endang. 2015. “Analisis Fitokimia”. Jakarta: Buku Kedokteran. EGC.

Handoko, A. D., Setyawati, T., Asrinawati, A. N. 2009. "Uji Efektivitas Antibakteri Ekstrak Daun Kersen (Muntingia Calabura L.) Terhadap Bakteri Escherichia Coli”. Jurnal Kedokteran. Universitas Tadulako. Vol.6. (1) Hal 18.

Harbone. 1987 ; Shaleh, Miftah Ulfah. 2016. "Uji Efek Antidiare Ekstrak Etanol Daun Kacang Gude (Cajanus Cajan (L.) Milla sp) Pada Mencit (Mus muculus). Makassar: Universitas Islam Negri Allaudin.

Hariana, H. Arief. 2008. "Tumbuhan Obat Dan Khasiatnya". Ed.2. Jakarta: Penebar Swadaya. Hal 118.

Kapti, R. E., Azizah, N. 2017. “Perawatan Anak Sakit di Rumah”. Malang: UBPress. Hal 1.

Kemenkes RI. 2017. "Profil Kesehatan Indonesia". Jakarta: Keputusan Mentri Kesehatan Republik Indonesia.

Kristina, Isminah, Leny Wulandari. 2008. Dalam Yasnita, Khori. 2018. "Uji Efek Antidiare Ekstrak Etanol Daun Laban (Vitex Quinata Lour. F.N. Williams) Terhadap Mencit Jantan". Medan : Universitas Sumatra Utara.

Mansjeor, dkk. 2001 ; Shaleh, Miftah Ulfah. 2016. "Uji Efek Antidiare Ekstrak Etanol Daun Kacang Gude (Cajanus Cajan (L.) Milla sp) Pada Mencit (Mus muculus). Makassar: Universitas Islam Negri Allaudin.

Mukhriani.2014 ; EM Sutrisna. 2016. "Herbal Medicine : Suatu Tinjauan Farmakologis". Surakarta : Muhammadyah Universitas Press

Musfirah, Y., Yulyan, T.G., Susiani, F.E. 2019. "Uji Aktivitas Antidiare Ekstrak Etanol Daun Mengkudu (Morinda Citrifolia L.) Pada Tikus Wistar Yang Diinduksi Bakteri Escherichia Coli”. Banjarmasin: Universitas Sari Mulia.

Mustcher. 1999 ; Yasnita, Khori. 2018. "Uji Efek Antidiare Ekstrak Etanol Daun Laban (Vitex Quinata Lour. F.N. Williams) Terhadap Mencit Jantan”. Medan: Universitas Sumatra Utara.

Nayak, B. S., Sandiford, S., dan Maxwell, A. (2007). Evaluation of the Wound-healing Activity of Ethanolic Extract of Morinda citrifolia L.Leaf. Evid Based Complement Alternative Medicine. Hal 351-356.

Neal, M. J. 2005 ; Anggun Purwaningsih Utami. 2019. "Uji Efektivitas Antidiare Ekstrak Etanol Daun Beluntas (Pluchea Indica L.) Terhadap Mencit Jantan (Mus musculus)". Tugas Akhir Studi Farmasi. Stikes Bhakti Husada Mulia Madiun.

Nelson, S. C. (2006). Morinda citrifolia (noni). Species Profiles for Pacific Island Agroforestry. http://www.agroforestry.net/tti/Morinda-noni.pdf. Online 2 Mei 2018.

Peter, P. I. (2007). Clinical Research on Morinda citrifolia L. Noni Clinical Research Journal. 1(1-2): Hal 4-10.

Prasetyo, A. D., Sasongko, H. 2014. "Aktivitas Antibakteri Ekstrak Etanol 70\% Daun Kersen (Muntingia Calabura L.) Terhadap Bakteri Bacillus Subtilis dan Shigella 
Dhsenteriae Sebagai Materi Pembelajaran Biologi SMA Kelas X Untuk Mencapai kd 3.4 Pada Kurikulum 2013”. Jurnal Pendidikan Biologi Universitas Ahmad Dahlan. Vol.1 (1) : hal 98-102.

Rasal, V. P., Sinnathambi, A., Ashok, P., dan Yeshmaina, S. (2008). Wound Healing and Antioxidant Activities of Morinda citrifolia Leaf Extract in Rats. Iranian Journal of Pharmacology \& Therapeutics.. Hal 49-52.

Saifudin A, Rahayu V, dan Teruna HY. 2011, Standardisasi Bahan Obat Alam, Yogyakarta : Graha Media.

Satwadhar, P. N., Deshpande, H. W., Syed, I. H., dan Syed K. A. (2011). Nutritional Composition and Identification of Some of The Bioactive Components in Morinda citrifolia Juice. International Journal of Pharmacy and Pharmaceutical Sciences. 3(1): Halaman 58-60.

Sukandar. 2008 ; Fajaryanti, Nita dan Kurniawati, Nunik ida. 2018. "Efek Antidiare Infusa dan Ciplukan (Physallis Angulata Linn) Pada Mencit Jantan Putih (Mus muculus) yang Terpapar Oleum Ricini”. Jurnal Farmasetis. Vol.7 (1) : Hal 19-22.

Sulaiman, dkk. 1990 ; Shaleh, Miftah Ulfah. 2016. "Uji Efek Antidiare Ekstrak Etanol Daun Kacang Gude (Cajanus Cajan (L.) Milla sp) Pada Mencit (Mus muculus). Makassar: Universitas Islam Negri Allaudin.

Suprapti, Lies. 2005. "Aneka Olahan Mengkudu Berkhasiat Obat". Yogyakarta: Kanisius. Hal 11.

Sutedjo. 2008 ; Shaleh, Miftah Ulfah. 2016. "Uji Efek Antidiare Ekstrak Etanol Daun Kacang Gude (Cajanus Cajan (L.) Milla sp) Pada Mencit (Mus muculus). Makassar: Universitas Islam Negri Allaudin.

Tampubolon, O.P. 1995. "Tumbuhan Obat". Jakarta: Bhratara.

Tan, H. T., dan Rahardja. K. 2002. "Obat-Obat Penting : Khasiat, Penggunaan, Dan Efek Sampingnya”. Edisi V. PT Elex Media Komputindo. Kelompok Gramedia. Jakarta.

Tarannita, Citra. Dkk. 2006. "Efek Hambatan Ekstrak Daun Ciplukan (Physallis Minima L.) Terhadap Kontrasilitas Otot Polos Usus Halus Terppisah Marmut Dengan Stimulasi Metrakolin Eksogen”. Jurnal kedokteran Brawijaya. Vol. 22 (1) : Hal 18-23.

Tarfiani, I. Nanda. 2018. "Uji Efektifitas Fraksi n-Heksana Daun Mengkudu (Morinda citrifolia L.) dengan Pembawa Vaselin Terhadap Penyembuhan Luka Sayat Pada Tikus". Medan: Universitas Sumatra Utara.

Thahir, Z., Azizah, N. A. 2019. "Uji Efek Antidiare Ekstrak Daun Mengkudu (Morinda citrifolia L.) Pada Mencit (Mus muscullus)". Makassar: Akademi Farmasi Yamasi.

Tjay, H. T., Rahardja. K. 2007. “Obat-Obat Penting”. Jakarta: PT Elex Media Komputindo. Hal 1.

Thomas, A.N.S. 1989. "Tanaman Obat Tradisional”. Yogyakarta: Kanisius. Hal 62.

Widiana, R., G. Indriati \& N. Harsinta. 2011. Daya Hambat Ekstrak Daun Mengkudu (Morinda Citrofolia L.) Terhadap Pertumbuhan Bakteri Penyebab Diare. Jurnal Saintek 3:1-5.

Widjaja, M. C. 2008. "Mengatasi Diare dan Keracunan pada Balita". Jakarta: Kawan Pustaka. Hal 4-6.

Yayasan Spritia. 2015. "Lembaran Informasi Tentang HIV dan AIDS Untuk Orang Yang Hidup Dengan HIV (Odha)”. Jakarta: Yayasan Spritia. hal 554. 